\title{
Idea bojaźni Bożej oraz sprawczej roli Boga w wojsku polskim i litewskim w epoce wczesnonowożytnej
}

\author{
The Idea of the Fearing of God and the \\ Causative Role of God in the Modern Age \\ Polish and Lithuanian Duchy Armies
}

\section{Abstrakt}

Artykuł analizuje rodzaj pobożności żołnierzy wczesnonowożytnych, który określany był jako „bojaźń Boża”. Zjawisko to wykształciło się w latach 60. XVI wieku, a następnie było kultywowane przez dwa stulecia, w armii polskiej i litewskiej. Polegało ono na wierze w bezpośrednią ingerencję Boga podczas działań militarnych, która była uzależniona od postępowania żołnierzy. Naczelni dowódcy promowali taką wizję rzeczywistości, w której przestępstwa utożsamiane z grzechami wpływały na rezultat wojen lub starcia, a nawet decydowały o bezpieczeństwie samych żołnierzy. Czyny niemiłe Bogu miały powodować surową karę zsyłaną podczas walk, a pobożność i dobre zachowanie gwarantowały sukces. Analizę tego zagadnienia przeprowadzono na podstawie wydawanych przez naczelnych dowódców aktów normatywnych, zwanych artykułami wojskowymi, co uzupełniono analizą traktatów wojskowych. W pracy zaakcentowano, że promowali tę koncepcję wszyscy dowódcy - niezależnie od wyznania, byli to zarówno bracia polscy, luteranie, ewangelicy reformowani, jak 
i katolicy. Umieszczano je - co do zasady - na początku artykułów wojskowych jako arengę, stanowiącą podstawę obowiązywania przepisów prawa karnego. Wykazano, że połączenie „bojaźni Bożej” z prawem wojskowym miało racjonalne powody - zapewniało wyższą dyscyplinę i morale, co mogło przełożyć się na skuteczność prowadzonych działań wojennych. Wykorzystanie tej idei umożliwiało rozbicie solidaryzmu żołnierskiego i stworzenie przekonania, że złe postępowanie pojedynczych osób wpływa na los oddziałów i całych armii. Do najważniejszych twórców tej koncepcji należy zaliczyć Floriana Zebrzydowskiego, Jana Chodkiewicza i Stanisława Cikowskiego, a na przełomie stuleci rozwinęli ją Jan Zamoyski i Krzysztof Radziwiłt, zwany Piorunem. Najbardziej rozbudowaną formułę w artykułach wojskowych zaprezentował w XVII stuleciu Krzysztof II Radziwiłł, a wiek później - Michał Kazimierz Radziwiłł. W artykule sformułowana została również hipoteza, że tę dawną koncepcję, która przetrwała jako jeden z elementów kultury staropolskiej, zaadaptowano do oceny Bitwy Warszawskiej z 1920 roku, która została określona jako Cud nad Wisłą, co miało symbolizować sprawczą rolę Boga podczas wojny.

Słowa klucze: pobożność, bojaźń Boża, religijność żołnierzy, religijność w epoce wczesnonowożytnej, prawo wojskowe, traktaty wojskowe, wojskowość wczesnonowożytna, wychowanie wojskowe

\section{Abstract}

This paper examines the type of devotion of the early modern soldiers which was referred to as "the fearing of God". The phenomenon started in the 1560s and continued for two centuries in the Polish and Lithuanian Duchy armies. It was based on the belief in the direct intervention of God during military action, which depended on the conduct of the soldiers. The commanders-in-chief promoted the vision of reality in which crimes were equated with sins and affected the outcome of wars and battles, and even determined the safety of the soldiers themselves. The acts that were displeasing to God were to result in severe punishment during battles, while piety and good behavior guaranteed success. The analysis of this issue was conducted on the basis of normative acts issued by the commanders-in-chief, called military articles, which were supplemented by the analysis of military treaties. The paper emphasizes that this concept was promoted by all commanders regardless of denomination, including Polish Brethren, Lutherans, Reformed Evangelicals and Catholics. It was placed, as a rule, at the beginning of the military articles as an arenga (proem), providing the basis for the validity of the criminal laws. The combination of the "fear of God" and the military law was shown to have rational justification: it guaranteed a higher discipline and morale, which could be reflected in the effectiveness of the warfare conducted. The application of this idea led to the breakdown of soldier solidarity and to 
the belief that the misconduct of individuals affected the fate of troops and entire armies. The most important creators of this concept include Florian Zebrzydowski, Jan Chodkiewicz and Stanisław Cikowski, and at the turn of the centuries it was developed by Jan Zamoyski and Krzysztof Radziwiłt, nicknamed Piorun (Thunder). The most elaborate formula in the military articles was presented in the 17th century by Krzysztof Radziwiłł II, and a century later by Michał Kazimierz Radziwiłt. A hypothesis was also formulated that an old concept, which survived as one of the elements of Old Polish culture, was adopted to evaluate the Battle of Warsaw of 1920, which has been referred to as the Miracle on the Vistula, what was supposed to symbolize the causal role of God during the war.

Keywords: piety, God fearing, religiosity of soldiers, religiosity in early modern era, military law, military treaties, early modern military, military education

Ważną rolę w dziejach dwudziestowiecznej Europy odegrała Bitwa Warszawska, stoczona w dniach od 13 do 25 sierpnia 1920 roku1. Wówczas Wojsko Polskie przełamało ofensywę Robotniczo-Chłopskiej Armii Czerwonej, co w konsekwencji doprowadziło do zawarcia pokoju w Rydze w 1921 roku pomiędzy Polską a Socjalistycznymi Republikami Radzieckimi (Rosyjską i Ukraińską)2 ${ }^{2}$. W życiu publicznym i prywatnym bardzo szybko nadano tym wydarzeniom narrację, którą w skrótowy sposób określano jako „Cud nad Wisłą”. Zgodnie z nią to Bóg, za pośrednictwem Maryi, miał zesłać zwycięstwo dla walczących pod Warszawą Polaków, a boska wola uzewnętrzniła się 15 sierpnia 1920 roku, czyli w święto Wniebowzięcia Najświętszej Marii Panny³. Kluczowe miały być przede wszystkim działania gen. Stanisława Hallera, który nakazał

1 Przykładowo: Janusz Cisek, Konrad Paduszek, Tadeusz Rawski, Wojna polsko-sowiecka 1919-1921 (Warszawa: Wojskowe Centrum Edukacji Obywatelskiej, 2010); Andrzej Nowak, Ojczyzna Ocalona. Wojna sowiecko-polska 1919-1920 (Kraków: Biały Kruk, 2012); Marian Kukiel, Bitwa Warszawska, wyd. Krzysztof Filipow, Zbigniew Wawer, (Warszawa: Polski Instytut Wydawniczy, 2005); Lech Wyszczelski, Bitwa na przedpolach Warszawy (Warszawa: Wydawnictwo Bellona, 2008).

2 Jerzy Borzęcki, Pokój ryski w 1921 roku i kształtowanie się między wojennej Europy Wschodniej (Warszawa: Polski Instytut Spraw Międzynarodowych, 2012).

3 Norman Davies, Biały orzeł, czerwona gwiazda. Wojna polsko-bolszewicka 1919-1920, tłum. A. Pawelec, (Kraków: Wydawnictwo Znak, 1997), 225-227; Lech Wyszczelski, Warszawa 1920 (Warszawa: Wydawnictwo Bellona, 2005), 322-344; Renata Hołda, „Wojna 1920 roku we współczesnym dyskursie pamięci”, w Ciekawość świata, ludzi, kultury... Księga jubileuszowa ofiarowana Profesorowi Ryszardowi Kantorowi z okazji czterdziestolecia pracy naukowej, red. Renata Hołda, Tadeusz Paleczny, (Kraków: Księgarnia Akademicka, 2012), 247-261. 
m.in. odprawienie ośmiodniowego nabożeństwa ${ }^{4}$. Jak słusznie zauważa Adam Bańdo, był to najważniejszy mit narodowy II RP i kształtował się głównie przez „nienaukowe przekazy, które utrwaliły go w świadomości społecznej jako wydarzenie opatrznościowe (metafizyczne) oraz

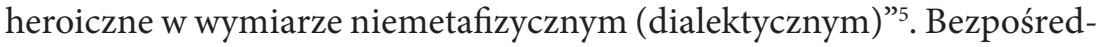
nio po bitwie Kościół katolicki bardzo aktywnie zaczął promować rolę Boga - Pana Historii. Zwornikiem osobowym tej narracji był ochotnik-kapelan ks. Ignacy Skorupka, który poległ, idąc w komży i z krzyżem w ręku w pierwszej linii atakujących żołnierzy. Jego bohaterstwo miało odrodzić ducha walki i podnieść morale u żołnierzy, a w konsekwencji odwrócić losy wojny ${ }^{6}$.

Zagadnienie to analizowane jest w licznych pracach historycznych, socjologicznych i politologicznych. Uważam jednak, że nazwa i związana z nią narracja nie zaadaptowałoby się tak dobrze w społeczeństwie, gdyby nie ciągłość kulturowa - zjawisko wykształcone w okresie wczesnonowożytnym. Wówczas w armii koronnej i litewskiej rozpowszechniło się przekonanie o bezpośredniej, namacalnej obecności mocy nadprzyrodzonych podczas walk, co skutkowało próbą budowania na tej koncepcji pobożności. Sama idea Boga - Pana Historii, obecna w armii wczesnonowożytnej, została już opisana w latach 2004-20077. Ustalenia tam poczynione przyjmuję jako punkt wyjścia, a w niniejszym artykule

4 Szukając genezy terminu, należałoby wskazać dziennik „Rzeczpospolita”, którego redaktorem naczelnym był Stanisław Stroiński. Był on przeciwnikiem polityki Józefa Piłsudskiego i już 14 VIII 1920 r. (w przeddzień Bitwy Warszawskiej) opublikował artykuł „O cud Wisły”, a tydzień później w felietonie „Wierna rzeka” zaakcentował rolę Hallera. Wiesław Władyka, „»Z fachu profesor..." (Stanisław Stroiński)”, Kwartalnik Historii Prasy Polskiej 31/3-4 (1992): 157-158.

5 Adam Bańdo, „Bitwa Warszawska 1920 r. w serwisie informacyjnym „Ilustrowanego Kuriera Codziennego" (w setną rocznicę "Cudu nad Wisłą )", Rocznik Historii Prasy Polskiej 23/2 (2020): 157.

6 Aleksander Kakowski, $Z$ niewoli do niepodległości. Pamiętniki (Kraków: Wydawnictwo Platan, 2000), 826-827; Adam Grzymała-Siedlecki, Cud Wisty. Wspomnienia korespondenta wojennego (Warszawa: Wiedza Powszechna, 1921), 121; Wiesław Jan Wysocki, „Kościół polski wobec najazdu bolszewickiego w 1920 roku”, w W nieustającej trosce o polską diasporę. Tom studiów historycznych i politologicznych dedykowany Księdzu Arcybiskupowi Szczepanowi Wesołemu, red. Roman Nir, Marek Szczerbiński, Krzysztof Wasilewski, (Gorzów Wielkopolski: Stowarzyszenie Naukowe „Polska w Świecie”, 2012), 91-96; Jacek Giejło, Bohater spod Ossowa: Ignacy Jan Skorupka: 1893-1920 (Warszawa: S.I. „Warta” Gorzów Wielkopolski, 2010).

7 Urszula Augustyniak, W służbie hetmana i Rzeczypospolitej. Klientela wojskowa Krzysztofa Radziwiłła (1585-1640) (Warszawa: Semper, 2004), 128-141; Karol Łopatecki, „Koncepcja Boga - Pana Historii wśród żołnierzy Rzeczypospolitej na przełomie XVI i XVII wieku", w Religia wobec historii, historia wobec religii, red. Elżbieta Przybył, (Kraków: Wydawnictwo WAM, 2006), 360-370. 
akcentuję rolę bojaźni Bożej ${ }^{8}$. Była to idea mocno propagowana w wojsku i stanowiła filar pobożności. Opierała się ona na przekonaniu, że grzech żołnierzy sprowadzał na całą zbiorowość karę, a sukces był uzależniony od Opatrzności ${ }^{9}$. Analizując to zjawisko, zastanawiam się także nad przełożeniem praktycznym - w szczególności nad jego wpływem na porządek i dyscyplinę w oddziałach ${ }^{10}$. Aby przeprowadzić analizę idei bojaźni Bożej, zgromadziłem w tabeli $\mathrm{nr} 1$ najważniejsze fragmenty promujące te wartości w artykułach wojskowych. Dzięki temu możliwe jest odtworzenie chronologii badanego zjawiska, kluczowych elementów i zachodzących przemian $^{11}$.

Dotychczasowe ustalenia wskazują, że żołnierze w armii polskiej i litewskiej 2. poł. XVI i 1. poł. XVII stulecia charakteryzowali się specyficznym światopoglądem ${ }^{12}$. Wynikało to $\mathrm{z}$ ich doświadczeń życiowych - niezwykle wyczerpujących fizycznie i psychicznie. Uczestnicząc w bitwach, szturmach, podjazdach i potyczkach, byli ciągle narażeni na ostrzał z broni palnej, artylerii, musieli również bezpośrednio walczyć z wrogiem z użyciem broni białej lub drzewcowej. W marszu i podczas obozowania armie trapiły epidemie, głód, groza ucieczki po przegranych starciach $^{13}$. Szukając przyczyn sukcesu i klęski, życia i śmierci, szczęścia i pecha, zaczęto odnajdywać koincydencję w bezpośredniej ingerencji

8 W religii chrześcijańskiej „bojaźń Boża” (łac. timor Dei) nie jest utożsamiana jedynie ze strachem (wynikającym z grzeszności człowieka wobec wielkości Boga) - jest to połączenie podziwu, czci, uwielbienia, zaufania, szacunku, a szczególnie miłości. Tomasz Nawracała, „»Bojaźń Pańska jest źródłem życia« (Prz 14, 27a). Rozwój pojęcia bojaźni Bożej w historii Kościoła", Ethos. Kwartalnik Instytutu Jana Pawła II KUL 27/4 (2014): 21-41.

9 Por. Marek Jędraszewski, „Opatrzność Boża w świetle filozofii”, Studia Theologica Varsaviensia 48/2 (2010): 63-91.

10 Porównawczo inspirujący jest tekst dotyczący wojskowości bizantyjskiej i wpływu na nią religii chrześcijańskiej. Michał Wojnowski, „Religia a wojskowość bizantyńska w świetle traktatów wojskowych IX-XI wieku", Przegląd Historyczny 100/2 (2009): 189-205. W pracy zaakcentowano wpływ religii na wysoką ocenę praktycznego myślenia, które skłaniało do unikania ryzyka i zapobiegania niepotrzebnym ofiarom. Stąd działania strategiczne i taktyczne charakteryzowały się daleko posuniętą ostrożnością i defensywnym charakterem działań.

11 Możliwość wykorzystania artykułów wojskowych do analizy zjawiska Boga - Pana Historii zasygnalizowano w pracy: Karol Łopatecki, „Religijność żołnierzy w świetle artykułów wojskowych - założenia metodologiczne”, Orientalia Christiana Cracoviensia 6 (2014): 89.

12 Poniższe rozważania na podstawie: Augustyniak, W służbie hetmana, 128-141; Łopatecki, Koncepcja Boga - Pana Historii, 360-370; vide również: Mirosław Lenart, Miles pius et iustus: żotnierz chrześcijański katolickiej wiary w kulturze i piśmiennictwie dawnej Rzeczypospolitej (XVI-XVIII w.) (Warszawa: Instytutu Badań Literackich PAN, 2009).

13 Tadeusz Srogosz, Życie codzienne żolnierzy armii koronnej i litewskiej w XVII wieku (Oświęcim: Napoleon V, 2018). 
Boga na ziemi ${ }^{14}$. To Stwórca decydował i rozstrzygał o losach bitew, wojen oraz pojedynczych istnień. Kolejnym krokiem była próba zrozumienia zachodzących wydarzeń i wykorzystania sił nadprzyrodzonych w doczesnym życiu. Sukces na wojnie można było uzyskać poprzez chrześcijańskie postępowanie i powstrzymywanie się przed złymi czynami, które sprowadzić mogły gniew Boży ${ }^{15}$. Oczywiście powyższe czynniki występowały na całym świecie i w różnych epokach ${ }^{16}$, jednakże różnica polegała na sposobie „kanalizacji” gromadzonych przeżyć i przekonań. W Rzeczypospolitej naczelni wodzowie świadomie zaczęli propagować koncepcję „bojaźni Bożej", która była przydatna do narzucenia żołnierzom dyscypliny wojskowej. Propagowanie idei determinizmu mogło zmusić żołnierzy do zmiany postępowania. Grzech nie oznaczał już kary w zaświatach, lecz należało oczekiwać jego skutków w życiu doczesnym; przybierał on również formę odpowiedzialności zbiorowej ${ }^{17}$. Z czasem koncepcja ta rozpowszechniła się w całym społeczeństwie i jej przejawy były widoczne zarówno w kulturze wysokiej, jak i masowej - licznie pojawiają się w pamiętnikach, diariuszach czy egodokumentach ${ }^{18}$. Symbolicznym ukoronowaniem tej

14 W sposób niezwykle wymowny łączył stan ciała i ducha Anton Schneeberger w wydanym w 1564 r. dziele: De Bona Militum Valetudine Conservanda Liber, oprac. R.A. Sucharski, T.M. Nowak, (Warszawa: DiG, 2008), 205-223. Stara się on omówić różne stany psychiczne żołnierzy jak strach, przerażenie, radość, smutek czy gniew.

15 Założenia te miały głębokie uzasadnienie biblijne. Liczne są przykłady gniewu Bożego, ale również i bezpośredniej pomocy udzielanej podczas walk. Dariusz Dziadosz, „Boża i ludzka wierność. Teologiczny obraz zdobycia Kanaanu”, Verbum Vitae 11 (2007): 43-66; Andrzej Krasowski, „Jozue - pomocnik Mojżesza i posłuszny wojownik Pana”, Itinera Spiritualia 8 (2015): 187-197; Mirosław Jasinski, „Motyw zwycięskiej modlitwy w narracji JOZ 10,1-27", Verbum Vitae 22 (2012): 15-46; Tomasz Siemieniec, „Bóg jako Pan historii świata i ludzi w świetle Apokalipsy Janowej”, Studia Koszalińsko-Kołobrzeskie 19 (2012): 129-155.

16 Przykładowo: Jacek Maciejewski, „Biskup krakowski Pełka a bitwa nad Mozgawą w 1195 roku”, Kwartalnik Historyczny 124/3 (2017): 411-438; Radosław Kotecki, „Ordynariusz płocki Szymon w Gallowej narracji o bitwie Mazowszan z Pomorzanami (Gall II, 49)", w Ecclesia et bellum. Kościót wobec wojny i zaangażowania militarnego duchowieństwa w wiekach średnich, red. Radosław Kotecki, Jacek Maciejewski, (Bydgoszcz: Wydawnictwo Uniwersytetu Kazimierza Wielkiego, 2016), 142-167; Paweł F. Nowakowski, „Kilka uwag o problemie dyscypliny w ruchu husyckim”, Episteme 16 (2012): 41-58; Paweł Krokosz, „Aspekt religijny w strukturach rosyjskich sił zbrojnych za panowania Piotra I", Україна в Центрально-Східній Європі 15 (2015): 210-236.

17 Łopatecki, Religijność żołnierzy, 81-94.

18 Marcin Bauer, „Religijny wymiar scen batalistycznych w pamiętnikach Samuela i Bogusława Kazimierza Maskiewiczów", Senoji Lietuvos literatūra 32 (2011): 103-114; Michał Kuran, „Struktura i problematyka kazań tryumfalnych Piotra Skargi wygłaszanych z okazji zwycięstw wojennych", Acta Universitatis Lodziensis. Folia Litteraria Polonica 21/3 (2013): 209-224; Jakub Pokora, „»Fortunae filius«: późnobarokowy portret Michała Hieronima Radziwiłła w Nieborowie", Saeculum Christianum 10/2 (2003): 23-35. 
koncepcji były słowa Jana III Sobieskiego, który po zwycięstwie pod Wiedniem doniósł papieżowi: Venimus, vidimus, et Deus vicit ${ }^{19}$.

Aby lepiej zrozumieć rozwijającą się w Rzeczypospolitej szlacheckiej koncepcję, w zamieszczonej poniżej tabeli znaleźć można zestawienie teoretycznego uzasadnienia odwołującego się do „bojaźni bożej” oraz wiary w sprawczą rolę Boga podczas wojen. Pomijam przy tym wszelkie fragmenty normatywne, m.in. nakazujące organizację i uczestnictwo w nabożeństwach, zakazujące używania przekleństw i stosowania czarów, znieważania duchownych itp. Oczywiście wymieniam jedynie akty, w których dostrzec można analizowane zjawisko, nie mamy zatem do czynienia $\mathrm{z}$ katalogiem enumeratywnym polskich lub litewskich artykułów wojskowych.

Tabela 1. Zestawienie informacji o Bogu - Panu Zastępów i bojaźni Bożej zawartych w artykułach wojskowych ${ }^{20}$

\begin{tabular}{|c|c|c|c|c|}
\hline L.P. & Autor & Wyznanie & Rok & Treść \\
\hline 1 & $\begin{array}{c}\text { Florian } \\
\text { Zebrzydowski }\end{array}$ & K & 1561 & $\begin{array}{l}\text { Tak też rozumieć musiemy, iż kto na koniu, ten bywa } \\
\text { i pod koniem, jako pospolicie Kozacy co czymbory } \\
\text { noszą mówią: iż tobie i mnie nie wiedzieć co komu } \\
\text { s[z]częście przyniesie. Acz my którzyśmy się w ten } \\
\text { okrąg, a spólne towarzystwo w zgodzie dali, Pan Bóg } \\
\text { i w miłości chrześci[j]ańskiej, w Panie Chrystusie zebrali, } \\
\text { a w łasce, a w miłosierdziu pańskim nic nie wątpiemy. } \\
\text { A wszakoż, iż dziwne i skryte są tajemnice pańskie, } \\
\text { a niepowściągnione drogi Jego, co wiedzieć, jeśli albo } \\
\text { prze występek pański, hetmański albo nas wszystkich, } \\
\text { społecznie Pan nie będzie raczył skarać, a gniewem } \\
\text { Swym ku uznaniu, a polepszeniu przywieść łaskawie21. }\end{array}$ \\
\hline
\end{tabular}

19 Michał Rożek, „Perigrinatio Religiosa”, Folia Historica Cracoviensia 4-5 (1997-1998): 223; Mieczysław Morka, „Tematyka batalistyczna w sztuce dworu Jana III”, Biuletyn Historii Sztuki 53/1-2 (1991): 20; Rafał Pawłowski, „Jan Sobieski jako czytelnik Biblii w świetle Listów do Marysieńki”, Tematy i Konteksty 6 (2016): 157-158.

20 Po liczbie porządkowej, w kolejnych dwóch kolumnach, podaję autora aktu normatywnego i jego wyznanie w momencie wydania praw. W czwartej kolumnie odnotowuję rok ogłoszenia praw, znakiem zapytania zaznaczając datę jedynie uprawdopodobnioną. Samą treść podaję na podstawie zasad instrukcji wydawniczej wypracowanej w zespole pod przewodnictwem Kazimierza Lepszego, natomiast jeżeli akty normatywne były już wydane w formie krytycznej, przepisuję ich treść bez ingerencji. Instrukcja wydawnicza dla źródet historycznych od XVI w. do poł. XIX w., red. Kazimierz Lepszy (Wrocław: Zakład im. Ossolińskich, 1953).

21 Российская национальная библиотека, Санкт-Петербург, Отдел рукописей, Автографи Дубравскаго (f. 971), 321/1, nr 1, k. 4. Słowo „сzymbory” w znaczeniu „cymbury”, czyli kajdany, więzy tatarskie (arkan). Antoni Muchliński, Źródło słownik wyrazów które przeszły, wprost czy pośrednio, do naszéj mowy z języków wschodnich... (Petersburg: Cesarska akademia Nauk, 1858), 19; Grażyna Rytter, Wschodniosłowiańskie zapożyczenia leksykalne w polszczyźnie XVII wieku (Łódź: Wydawnictwo Uniwersytetu Łódzkiego, 1992), 14. 


\begin{tabular}{|c|c|c|c|c|}
\hline L.P. & Autor & Wyznanie & Rok & Treść \\
\hline 2 & $\begin{array}{c}\text { Jan } \\
\text { Chodkiewicz }\end{array}$ & $E-R$ & 1564 & $\begin{array}{l}\text { Naprzod w wojsce bogobojności i posłuszeństwa jest } \\
\text { potrzeba, przeto każdy według najwiętszego uważenia } \\
\text { sumnienia swego P. Boga na wszelki czas przed oczy- } \\
\text { ma mieć ma, chceli, aby sprawy jego na wszem sie } \\
\text { przystojnie okazały22. }\end{array}$ \\
\hline 3 & $\begin{array}{l}\text { Stanisław } \\
\text { Cikowski }\end{array}$ & $\mathrm{BP}$ & 1565 & $\begin{array}{l}\text { Naprzod przypomniał, aby bojaźń Boża była między } \\
\text { nami, chcemyli, aby nam P. Bog na tej drodze fortunił } \\
\text { a nam wodzem i przewodnikiem był23. }\end{array}$ \\
\hline 4 & $\begin{array}{c}\text { Krzysztof } \\
\text { Myszkowski }\end{array}$ & K & 1572 & $\begin{array}{l}\text {... albowiem gdzie jest kaźń, tam też i bojaźń, tam } \\
\text { miłość i rząd, a przodkiem łaska Boża, ktorej każdemu } \\
\text { nadewszytko potrzeba }{ }^{24} \text {. }\end{array}$ \\
\hline 5 & $\begin{array}{c}\text { Mikołaj } \\
\text { Mielecki (?) }\end{array}$ & $E-R$ & $1572 ?$ & $\begin{array}{l}\text { Naprzod i nadewszystko wszyscy starać się mają, aby } \\
\text { mieli przed oczyma bojaźń Bożą, ktora dodaje dobrego } \\
\text { serca: bo z kim Bog, dobrze się mu powodzić będzie }{ }^{25} \text {. }\end{array}$ \\
\hline 6 & Stefan Batory & K & 1581 & $\begin{array}{l}\text { A iż jako inne rzeczy dobre wszytkie, tak tym więcej } \\
\text { zwycięstwa od Pana Boga są, tedy żeby Pan Bog tej } \\
\text { teraźniejszej sprawie naszej błogosławić i w tym, co } \\
\text { przedsiębierzemy, pomocnym nam być raczeł, każdy } \\
\text { z przełożonych i panow ma swoich napominać, i do } \\
\text { tęgo więc, aby każdy tu teraz osobliwie bojaźń Boga } \\
\text { przed oczyma miał, onemu sie modlił i jako napilniej } \\
\text { o to sie starał, aby sumnienie swe, jako naczystsze być } \\
\text { może, Panu Bogu oddawał²6. }\end{array}$ \\
\hline 7 & Jan Zamoyski & K & 1589 & $\begin{array}{l}\text { Idąc do tej potrzeby RP każdy ma u siebie uważać } \\
\text { z kiem i o czo do czynienia nam przychodzi, to jest że } \\
\text { z pogany o zdrowia, żywoty, wolnoścz, a insze wszyst- } \\
\text { ko co może być najmilszego, a nawięczy dlia wiary } \\
\text { Ś. Chrześcijańskiej. Przeto tedy, iż wszystkie siły nasze, } \\
\text { by też beły największe, bez łaski i błogosławieństwa } \\
\text { bożego mdłe i nikczemne są, gdyż On sam ma zwy- } \\
\text { czięstwa w ręku swoich na małoścz albo wielkocz wojsk } \\
\text { nie patrząc daje on. To jest najpierwsze napomnienie } \\
\text { abyśmy w bojaźni bożej do tej potrzeby przystępowali, } \\
\text { a przez modlitwy, łaski i błogosławieństwa jego prosili, } \\
\text { czo gdy czynić będziem wątpić nie potrzeby, że rady } \\
\text { s[z]czera i sieły Pan Bóg nam dodawać będzię27. }\end{array}$ \\
\hline
\end{tabular}

22 Polskie ustawy i artykuły wojskowe od XV do XVIII wieku, wyd. Stanisław Kutrzeba, (Kraków: Polska Akademia Umiejętności, 1937), 120.

23 Ibidem, 124.

24 Ibidem, 142.

25 Ibidem, 305.

26 Ibidem, 154.

27 Artykuły wojskowe Jana Zamoyskiego, Trembowla 18 X 1589, Biblioteka Książąt Czartoryskich, rkps 1621, s. 485. 


\begin{tabular}{|c|c|c|c|c|}
\hline L.P. & Autor & Wyznanie & Rok & Treść \\
\hline 8 & Jan Zamoyski & K & 1593 & $\begin{array}{l}\text { Od samego Pana Boga każde zwycięstwo, gdyż on jest } \\
\text { Bogiem wojsk i zastępów i rotmistrz tedy każdy i każdy } \\
\text { w rociech jego ma na każdy dzień modlitwy swe Panu } \\
\text { Bogu oddawać28. }\end{array}$ \\
\hline 9 & $\begin{array}{l}\text { Krzysztof } \\
\text { Radziwiłł } \\
\text { Piorun }\end{array}$ & $E-R$ & 1601 & $\begin{array}{l}\text { Albowiem we wszelakim stanie, a zwłaszcza w rycer- } \\
\text { skim nie bez porządku dobrze stać i dziać się nie może, } \\
\text { bo gdzie karanie jest naznaczone tam bojaźn i pra- } \\
\text { wo zachowane. A gdzie się to najduje tam porządek } \\
\text { i miłość, a naprzód łaska Boża, która nade wszystko } \\
\text { każdemu człowiekowi nawięcej jest potrzeba. Naprzód } \\
\text { najpilniej się starać aby w nas bojaźn Boża była, któ- } \\
\text { rą gdy zawsze przed oczyma mieć będziemy a serca } \\
\text { i sprawy nasze do niej obrociemy bez pochyby, że Pan } \\
\text { Bóg z nami i we wszelkim dobrze się nam powiedzie }\end{array}$ \\
\hline 10 & $\begin{array}{l}\text { Sejm } \\
\text { (Adam } \\
\text { Prusinowski?) }\end{array}$ & $\begin{array}{c}\text { dominują- } \\
\text { cy K }\end{array}$ & 1609 & $\begin{array}{l}\text { lż od samego Pana Boga każde zwycięstwo, bo on } \\
\text { jest Bogiem wojsk i zastępow, rotmistrz tedy ma to } \\
\text { mieć na pieczy, żeby się i sam Pana Boga bał i swym } \\
\text { przykładem i napominaniem wiodł do bojaźni Bożej } \\
\text { i pobożnego i przystojnego życia towarzysze, a oni } \\
\text { także pacholiki swe }{ }^{30} \text {. }\end{array}$ \\
\hline 11 & $\begin{array}{l}\text { Krzysztof } \\
\text { Radziwiłł? }\end{array}$ & $E-R$ & $1617 ?$ & $\begin{array}{l}\text { lż od samego Pana Boga każde zwycięstwo, bo on jest } \\
\text { Bogiem wojsk i zastępów, ma każdy rotmistrz to mieć } \\
\text { na baczeniu, żeby się i sam Pana Boga bał i przykładem } \\
\text { swym do pobożnego i przystojnego życia był powodem } \\
\text { towarzyszowi }{ }^{31} \text {. }\end{array}$ \\
\hline 12 & $\begin{array}{l}\text { Krzysztof } \\
\text { Radziwiłł }\end{array}$ & $E-R$ & 1618 & $\begin{array}{l}\text { Jako wszelkie błogosławieństwo od Boga samego } \\
\text { pochodzi, tak osobliwie duet wojennych spraw pro- } \\
\text { wadzić się bez jego s[z]częśliwie nie może. On bowiem } \\
\text { jest Panem Zastępów i wojska swej trzyma władzy. } \\
\text { Przeto każdemu rycerskiemu człowiekowi napierwej } \\
\text { to ma być na baczeniu, aby się P. Boga bał, rotmistrz } \\
\text { aby do pobożnego i przystojnego życia był powodem } \\
\text { towarzyszowi. Towarzysz zaś złego nie dawał z siebie } \\
\text { czeladzi swej przykładu²2. }\end{array}$ \\
\hline
\end{tabular}

28 Polskie ustawy, 341.

29 Российская национальная библиотека, Санкт-Петербург, Отдел рукописей, Автографи Дубравскаго (f. 971), 321/1, nr 141, k. 91.

30 Polskie ustawy..., 176, oraz z niewielkimi odmianami Volumina Legum, t. 2 (Petersburg: Józefat Ohryzko, 1859) 476. Sformułowanie „Bóg zastępów” jest bezpośrednim zapożyczeniem ze Starego Testamentu (Joz 5,13-15): Dariusz Antoni Dziadosz, „Ideowy i teologiczny podtekst misji "wodza zastępów JHWH« w Joz 5, 13-15", Biblica et Patristica Thoruniensia 13/1 (2020): 25-58.

31 Российская национальная библиотека, Санкт-Петербург, Отдел рукописей, Автографи Дубравскаго (f. 971), 321/2, nr 283, k. 1.

32 Российская национальная библиотека, Санкт-Петербург, Отдел рукописей, Автографи Дубравскаго (f. 971), 321/2, nr 42, k. 1. 


\begin{tabular}{|c|c|c|c|c|}
\hline L.P. & Autor & Wyznanie & Rok & Treść \\
\hline 13 & $\begin{array}{c}\text { Władysław IV } \\
\text { (nawiązują } \\
\text { do aktu } \\
\text { wydanego } \\
\text { przez Gustawa } \\
\text { II Adolfa) }\end{array}$ & $\begin{array}{c}\mathrm{K} \\
\text { (nawiązują } \\
\text { do L) }\end{array}$ & 1633 & $\begin{array}{l}\text { Ponieważ wszytko szczęście, powodzenie dobre i bło- } \\
\text { gosławieństwo od Boga wszechmogącego jako z nie- } \\
\text { przebranego źródła płynie, tedy wprzód i najbar[d]ziej } \\
\text { przestrzegać tego potrzeba, żeby się bojaźń Boża wszę- } \\
\text { dy, najbar[d]ziej w sercach ludzi wojennych wkorzeniła } \\
\text { prawdziwie, służba Boża w wojsku naszym odprawowa- } \\
\text { ła, zaczym żadnego bałwochwalcę, czarownika, wroż- } \\
\text { ka, zaklinacza w osadach ani na stanowiskach między } \\
\text { naszym żołnierstwem cierpieć nie chcemy }{ }^{33} \text {. }\end{array}$ \\
\hline 14 & $\begin{array}{l}\text { Krzysztof } \\
\text { Radziwiłł }\end{array}$ & $E-R$ & 1633 & $\begin{array}{l}\text { Iż Pan Bóg jest authorem wszystkiego dobrego, a pogo- } \\
\text { towiu wszelkiego szczęścia i sukcessów pomyślnych na } \\
\text { wojnie i w ręku jego jest zwycięstwom i triumfy szafo- } \\
\text { wać, przeto każdy żołnierz ma wszystkie sprawy swoje } \\
\text { od wzywania imienia jego zaczynać, jemu się gorąco } \\
\text { każdy według swego nabożeństwa modlić i jego miło- } \\
\text { sierdzia świętego pokornie i często prosić, aby nam } \\
\text { sam błogosławić i nieprzyjaciela stłumić raczył. Co aby } \\
\text { u majestatu jego świętego uprosić tym snadniej mogło, } \\
\text { tedy warować się tych rzeczy każdy ma, któremu się } \\
\text { oko jego święte brzydzi, jako są zdzierstwa, łupiestwa, } \\
\text { ciemiężenie ubogich ludzi, cudzołóstwa, wszeteczeń- } \\
\text { stwa, pijaństwa, kosterstwa zbytki wszelkie i insze tym } \\
\text { podobne grzechy34. }\end{array}$ \\
\hline 15 & $\begin{array}{l}\text { Krzysztof } \\
\text { Radziwiłł }\end{array}$ & $E-R$ & 1635 & $\begin{array}{l}\text { Naprzod i nadewszytko wszyscy mają mieć przed oczy- } \\
\text { ma bojaźn Bożą, ta bowiem obozow i wojska broni, ta } \\
\text { krolom, hetmanom i rycerstwu dodaje dobrego serca, } \\
\text { gdyż Bog jest Bogiem wojsk i panem zastępow, On } \\
\text { w pobożnych i cnotliwych obozach przemieszkiwa, a na } \\
\text { niepobożne wojska strach, hańbę i przegraną dopusz- } \\
\text { cza. Każdy tedy rycerski człowiek o powołanie swoje } \\
\text { rycerskie z bojaźnią Bożą niech odprawuje, strzegąc się } \\
\text { i uczynkow Majestat Boży obrażających i mow lada- } \\
\text { jakich o Bogu albo przeciwko Bogu bluźnierskich. Do } \\
\text { czego pułkownicy, rotmistrze towarzystwu, towarzystwo } \\
\text { czeladzie swojej dobry przykład z siebie dawać mają. } \\
\text { A ktoby w tym występny i nieprzykładny był, tego } \\
\text { hetman, obawiając się, aby sam z wojskiem od Boga } \\
\text { pokarany nie był, karać surowo będzie } 35 \text {. }\end{array}$ \\
\hline
\end{tabular}

33 Российская национальная библиотека, Санкт-Петербург, Отдел рукописей, Автографи Дубравскаго (f. 971), 321/1, nr 243, k. 1; Polskie ustawy... s. 210. Arenga stanowi powtórzenie szwedzkich artykułów wojskowych uchwalonych przez Gustawa II Adolfa (L). Schwedisches Kriegs-Recht oder Articuls-Brieff desz... Herrns Gustaff Adolfs..., Heylbrunn 1632, 5.

34 Российская национальная библиотека, Санкт-Петербург, Отдел рукописей, Автографи Дубравскаго (f. 971), 321/2, nr 197, k. 1.

35 Polskie ustawy..., 234-235. 


\begin{tabular}{|c|c|c|c|c|}
\hline L.P. & Autor & Wyznanie & Rok & Treść \\
\hline 16 & $\begin{array}{c}\text { Janusz } \\
\text { Radziwiłł }\end{array}$ & $E-R$ & 1648 & $\begin{array}{l}\text { Iż pan Bog jest autorem wszystkiego dobrego a pogo- } \\
\text { towiu wszelakiego szczęścia i sukcesow pomyślnych } \\
\text { na wojnie i w ręku jego jest zwycięstwem i tryumfem } \\
\text { szafować, przeto każdy żołnierz ma wszystkie sprawy } \\
\text { swoje od wzywania imienia jego zaczynać, jemu się } \\
\text { gorąco każdy według swego nabożeństwa modlić } \\
\text { i jego miłosierdzia pokornie prosić, aby nam sam } \\
\text { błogosławić i nieprzyjaciela stłumić raczył. Co aby } \\
\text { u majestatu jego świętego uprosić tym snadniej się } \\
\text { mogło, tedy warować się tych rzeczy każdy ma, a kto- } \\
\text { remi się jego ś. kościoł brzydzi, jako są zdzierstwa, } \\
\text { łupiestwa, uciemiężenie ubogich ludzi, cudzołostwa, } \\
\text { wszeteczeństwa, pijaństwa, kostyrstwa wszelakie i inne } \\
\text { tym podobne grzechy }{ }^{36} \text {. }\end{array}$ \\
\hline 17 & Konfederackie & $\begin{array}{c}\text { Dominują- } \\
\text { cy K }\end{array}$ & 1659 & $\begin{array}{l}\text { Iż wszelkie dobro i szczęście i wszystkich na świecie rze- } \\
\text { czy skutek dobry pochodzi z błogosławieństwa Bożego, } \\
\text { a błogosławieństwo Boże z bojaźni jego świętej, bojaźń } \\
\text { zaś z kary i sprawiedliwości, przeto i my w dochodzeniu } \\
\text { zasług naszych krwawych, chcąc mieć karę na wstępie } \\
\text { artykuły dobrowolnie na samych siebie układamy³. }\end{array}$ \\
\hline 18 & Konfederackie & $\begin{array}{c}\text { Dominują- } \\
\text { cy K }\end{array}$ & 1661 & $\begin{array}{l}\text { Że wszelakie szczęście i wszystkie na świecie rzeczy } \\
\text { pochodzą z błogosławieństwa Bożego, z bojaźni Jego } \\
\text { świętej, a bojaźń ze sprawiedliwości, przeto i my } \\
\text { w dochodzeniu zasług naszych krwawych chcąc mieć } \\
\text { karę na występne te artykuły dobrowolnie na samych } \\
\text { siebie uchwaliwszy }\end{array}$ \\
\hline 19 & $\begin{array}{c}\text { Michał } \\
\text { Kazimierz Pac }\end{array}$ & K & 1673 & (Identyczna z rokiem 1635) \\
\hline 20 & August II & $\mathrm{L} / \mathrm{K}$ & 1698 & $\begin{array}{l}\text { Ponieważ wszelkiego błogosławieństwa, pomyślnego } \\
\text { powodzenia i szczęśliwości jedynie i szczególnie od naj- } \\
\text { dobrotliwszego dostąpić możemy Boga, tak a powinien } \\
\text { będzie każdy pilnie starać się o to, aby chrześcijański } \\
\text { i bogobojny żywot prowadził, strzegąc się bezecnych } \\
\text { i z gorszących spraw }{ }^{40} \text {. }\end{array}$ \\
\hline
\end{tabular}

36 Ibidem, 261.

37 Biblioteka Książąt Czartoryskich, rkps 2446, 199.

38 Stefan Franciszek Medeksza, Księga pamiętnicza, wyd. Władysław Seredyński (Kraków: Akademia Umiejętności, 1875), 231. Podobne: Biblioteka Książąt Czartoryskich, rkps 1661, s. 1; Санкт-Петербургский институт истории РАН, Западноевропейска секциа, kolekcja 32, karton 660, ор. 2, 169.

39 Polskie ustawy..., 253.

40 Ibidem, 292. Szerzej o konwersji Augusta II: Dariusz Milewski, „Koronacja Augusta II Mocnego na króla Polski”, Saeculum Christianum 10 (2003): 85. 


\begin{tabular}{|c|c|c|c|c|}
\hline L.P. & Autor & Wyznanie & Rok & Treść \\
\hline 21 & $\begin{array}{l}\text { Hieronim } \\
\text { Radziwiłł }\end{array}$ & K & 1733 & $\begin{array}{l}\text { Ponieważ wszystko szczęście i powodzenie dobre i bło- } \\
\text { gosławieństwo od Boga wszechmogącego jako z nie- } \\
\text { przebranego źrzódła płynie, tedy wprzody najbardziej } \\
\text { przestrzegać tego trzeba, żeby się bojaźń Boża wszę- } \\
\text { dy, najbardziej w sercach ludzi wojennych wkorzeniła } \\
\text { prawdziwa służba Boża }{ }^{41} \text {. }\end{array}$ \\
\hline 22 & $\begin{array}{c}\text { Michał } \\
\text { Kazimierz } \\
\text { Radziwiłł }\end{array}$ & K & 1746 & $\begin{array}{l}\text { lż wszystkie dzieła chrześciańskie na gruncie bojaźni } \\
\text { Bożej stanowione być powinny, bo ta królom, het- } \\
\text { manom i rycerstwu dodaje serca, ta obozów i wojsk } \\
\text { broni, gdyż Bóg jest Bogiem Wojsk, Panem Zastępów, } \\
\text { on w pobożnych i cnotliwych przebywa obozach, a bez- } \\
\text { bożne karze, tłumiąc je i wszelkiej im ubliżając pomocy, } \\
\text { każdy tedy rycerski człowiek wokatio swoją na bojaźni } \\
\text { Bożej zakładać powinien, strzegąc się cokolwiek z obra- } \\
\text { zą Najwyższego Majestatu Boskiego być może w przy- } \\
\text { stojnym i cnotliwym życiu, prowadząc stanie, do czego } \\
\text { zwierzchność każda swojej przykładem i powodem byćć } \\
\text { powinna komendzie i chwale Pana Boga }{ }^{42} \text {. }\end{array}$ \\
\hline 23 & August III & K & $1749 ?$ & $\begin{array}{l}\text { Naprzód jako wszelkiego błogosławieństwa, pomyślne- } \\
\text { go powodzenia i szczęśliwości, szczególnie od Najdo- } \\
\text { brotliwszego dostąpić możemy, Bogu tak winien będzie } \\
\text { każdy starać się pilnie, aby wszelkich niestrzemięźli- } \\
\text { wych i gorszących strzegąc się spraw w chrześcijańskich } \\
\text { i bogobojnych postępkach życie prowadził }{ }^{43} \text {. }\end{array}$ \\
\hline 24 & $\begin{array}{c}\text { Michał } \\
\text { Kazimierz } \\
\text { Radziwiłł }\end{array}$ & K & 1754 & $\begin{array}{l}\text { Ponieważ szczęście, błogosławieństwo i wszystko dobre } \\
\text { od Boga wszechmogącego jako prawdziwego źrzodła } \\
\text { płynie i pochodzi, ktory od każdego chrześcijanina } \\
\text { ma być nabożnie wzywany, i, jako się nam w Słowie } \\
\text { świętym objawić raczył chwalony, przeto w każdym } \\
\text { przedsięwzięciu swoim wszelkiego czasu i w najmniej- } \\
\text { szej okazjej pilne każdemu należy mieć na to baczenie, } \\
\text { aby się nie działa jego świętemu imieniowi należytej } \\
\text { ujma chwały }{ }^{44} \text {. }\end{array}$ \\
\hline
\end{tabular}

Opracowanie własne - podstawa źródłowa każdorazowo podana przy przytoczonych cytatach. Stosowane skróty wyznań: katolickie $(\mathrm{K})$, ewangelicko-reformowane (E-R), luterańskie (L), bracia polscy (BP). Znak „?” oznacza niepewną informację.

41 Archiwum Główne Akt Dawnych, Archiwum Radziwiłłów VII, sygn. 5, 41.

42 Archiwum Główne Akt Dawnych, Archiwum Radziwiłłów VII, sygn. 5, s. 47.

43 Biblioteka Ossolińskich, Biblioteka im. Gwalberta Pawlikowskiego, rkps 12, s. 18.

44 Artykvty woienne powaga Rzeczy Pospolitej krolow polskich y Hetmanów W.X. Litt. rożnymi czasy ustanowione. Teraz zaś z rozkazu Iaśnie Oświeconego Xiążęcia Iegomości Michała V Kazimierza Radziwiłła (...) przedrukowane (Nieśwież: Drukarnia Xiążęca Radziwiłłów in Collegio Societatis, 1754), 93. 
Dotychczasowe opracowania badały to zagadnienie do połowy XVII wieku. Dane z tabeli wskazują, że koncepcja ta rozwinęła się w latach 60. i 70. XVI stulecia i z powodzeniem istniała zarówno w 2. poł. XVII, jak i w 1. poł. XVIII wieku ${ }^{45}$. Na potwierdzenie tej tezy warto przywołać dzieło Jana Michała Kampenhausena (1680-1742) Obserwacje do wojennych operacji $i$ akcji ${ }^{46}$. Ten mieszkaniec Inflant pod koniec pierwszego dziesięciolecia przeszedł na służbę polską, a jako teoretyk wojskowy zasłynął w trzecim i czwartym dziesięcioleciu XVIII wieku, stając się najważniejszym przedstawicielem wojskowości staropolskiej tego stulecia ${ }^{47}$. W pierwszym rozdziale przywołanego dzieła, zatytułowanym „O bojaźni boskiej”, dokładnie powtórzył zasady obowiązujące w świetle koncepcji Boga - Pana Historii ${ }^{48}$. Zwrócił uwagę, że wódz i oficer powinien być osobą pobożną i nakłaniającą do tego samego swoich podwładnych. Pożądane cechy miały być realizowane poprzez modlitwy organizowane dwa razy dziennie oraz nabożeństwa. O pomoc Bożą miano się zwracać „we wszystkich akcjach (...) a najbardziej przed bitwą”. W szczegółach odwoływał się do treści artykułów wojskowych.

Natomiast omawiane zjawisko w czasach stanisławowskich już nie występuje, w szczególności brak analogicznych odwołań w kodyfikacji prawa wojskowego z 1775 roku $^{49}$. Możliwa jest zatem korelacja polegająca na wyparciu analizowanej koncepcji „bojaźni Bożej” przez idee oświeceniowe $^{50}$. Zresztą już wcześniej, od końca XVII wieku, arengi ulegają skróceniu i ich treść staje się uboższa, coraz częściej też akty pozbawione są jakichkolwiek analogicznych fragmentów ${ }^{51}$.

45 Zwraca na to uwagę: Jerzy Ronikier, Hetman Adam Sieniawski i jego regimentarze. Studium z historii mentalności szlachty polskiej 1706-1725 (Kraków: Universitas, 1992), $25-36$.

46 Biblioteka Kórnicka PAN, rkps 659; Biblioteka Książąt Czartoryskich, rkps 2717. Traktat ten nadal czeka na naukowe opracowanie i edycję źródłową.

47 Andrzej Sikorski, Spolonizowane rodziny inflanckie. I. Kampenhausenowie, http:// www.bkpan.poznan.pl/ biblioteka/JW70/kampen.htm (dostęp: 12.07.2021); Rafał Nestorow, „Jan Kampenhausen. Inżynier na usługach hetmana Adama Mikołaja Sieniawskiego", w Fides Ars Scientia. Studia dedykowane pamięci Księdza Kanonika Augustyna Mednisa, red. Andrzej Betlej, Józef Skrabski, (Tarnów: Muzeum Okręgowe w Tarnowie, 2008), 315-326.

48 Biblioteka Kórnicka PAN, rkps 659, k. 10-10v.

49 Artykuty woyskowe = Kriegs-Artikel (Warszawa: 1775).

50 Wojciech Organiściak w pracy Kodeksy wojskowe w Polsce roku 1775 (Katowice: Wydawnictwo Uniwersytetu Śląskiego, 2001) łączy idee oświeceniowe z kodyfikacją prawa wojskowego w $1775 \mathrm{r}$.

51 Wyjątek stanowią artykuły wojskowe Michała Kazimierza Radziwiłła z 1746 r. 
Początek budowania idei bojaźni Bożej wśród żołnierzy wiąże z I wojną północną (1558-1570), a jej propagatorami byli zarówno Polacy, jak i Litwini, w szczególności należy wymienić Floriana Zebrzydowskiego, Jana Chodkiewicza i Stanisława Cikowskiego. Jeszcze w okresie poprzedzającym wojnę w Inflantach hetman wielki koronny Jan Tarnowski nie promuje idei bojaźni Bożej. W traktacie Consilium Rationis Bellicae na końcu rozdziału dotyczącego dowódcy wojsk zawarł interesujący akapit $^{52}$. Połączył w nim dwa zagadnienia - umiejętności wojskowe i „łaskę Bożą" (utożsamianą ze szczęściem). Celem Tarnowskiego jest podkreślenie cechy ostrożności, którą przeciwstawia lekkomyślności i zadufaniu we własną wiedzę. Według hetmana, nikt podczas wojny nie jest nieomylny, a wiedza książkowa jest wrogiem intuicji. Pobożność hetmana miała opierać się na przejawach religijności zewnętrznej - widocznej dla postronnych, niekoniecznie jednak powinien stosować się do wskazówek etycznych podczas wojny.

Aby zobrazować to zjawisko, warto przytoczyć brutalne słowa, często wypowiadane przez Tarnowskiego: „Kurwa, z odpuszczeniem nabożna, a hetman miełosierny wszytko to jednego cechu" ${ }^{\prime 3}$. Pisze o tym Stanisław Sarnicki, który jednocześnie starał się umniejszyć znaczenie stosowanego przez hetmana powiedzenia. Jeżeli jednak weźmiemy pod uwage czyny Tarnowskiego, odnajdziemy w stosowanym cytacie dużo prawdy o postępowaniu Lelewity. U tego renesansowego wodza liczył się przede wszystkim utylitaryzm, czego uzewnętrznieniem było zdobycie Starodubu w 1535 roku, a następnie zamordowanie około 1000-1400 wziętych do niewoli jeńców ${ }^{54}$. Oczywiście nie oznacza to, że Jan Tarnowski lekceważył pobożność - doceniał jej rolę jako elementu pozytywnie oddziaływającego na żołnierzy. Przeciwny był jednak samoograniczeniu wodzów w świetle koncepcji „bojaźni Bożej”, zamiast niej akcentował "łaskę Boską"55.

52 Jan Tarnowski, Consilium Rationis Bellicae, oprac. Tadeusz Marian Nowak, wstęp Janusz Sikorski, (Warszawa: MON, 1987), 97 i 99.

53 Stanisław Sarnicki, Księgi hetmańskie, oprac. Marek Ferenc, (Kraków: Historia Iagiellonica, 2015), 33.

54 Михаил Маркович Кром, Стародубская война 1534-1537. Из истории руссколитовских отношений (Москва: Рубежи XXI, 2008), 74-83; Włodzimierz Dworzaczek, Hetman Jan Tarnowski. Z dziejów możnowładztwa małopolskiego (Warszawa: Pax, 1985), 75-77.

55 Trzeba przy tym zaznaczyć, że był on wielkim zwolennikiem dyscypliny wojskowej, która miała się uzewnętrznić ograniczeniem samowoli. A zatem wprowadził on ogólny zakaz krzywdzenia ludności cywilnej, nawet nieprzyjacielskiej - co można uznać za stworzenie podstaw humanitarnego prawa wojny. Karol Łopatecki, „Czy Jan Tarnowski jest twórcą prawa wojskowego na terenie Korony i Wielkiego Księstwa 
Do głównych pomysłodawców omawianej idei należy zaliczyć Floriana Zebrzydowskiego, uzdolnionego teoretyka wojskowości i doświadczonego żołnierza $^{56}$. On to w 1561 roku publikując artykuły hetmańskie, pod koniec aktu normatywnego szerzej zają się problemem zwycięstwa i klęski podczas wojen. Zwrócił uwagę, że jednostkowe szczęście i pech, sukces lub porażka jest kwestią niezbadaną. Z tekstu można wyczytać, że żołnierze zgromadzeni w kole wojskowym w celu akceptacji artykułów, dokonali wspólnej deklaracji ${ }^{57}$. Na niej razem złożyli swój los w ręce Boga. Po raz pierwszy w prawie wojskowym odwołano się również do koncepcji „bojaźni Bożej” oraz do zbiorowego karania za grzechy żołnierzy. Charakterystyczne, że oczekiwano kary ojcowskiej, która miała skutkować poprawą zachowania całej zbiorowości.

Następni dowódcy - Jan Chodkiewicz i Stanisław Cikowski - przenieśli te rozważania na początek artykułów hetmańskich. Miało to niebagatelne znaczenie. To nie tylko hierarchizowało porządek prawny (prawo wojskowe znalazło umocowanie w prawie Bożym), ale również silniej oddziaływało na żołnierzy. Cechą artykułów wojskowych było cykliczne, nierzadko nawet cotygodniowe, czytanie ich wszystkim żołnierzom ${ }^{58}$. Z oczywistych względów początek więc miał dużą wagę, był bez problemu zapamiętywany. Ten fragment aktu normatywnego nabrał charakteru arengi, która uzasadniała konieczność stosowania prawa wojskowego.

Więcej uwagi należy poświęcić regulacjom ogłoszonym przez Stanisława Cikowskiego, który należał do wspólnoty braci polskich ${ }^{59}$. Jako pierwszy używa terminu „bojaźń Boża”, wielokrotnie też przy poszczególnych przestępstwach odwołuje się bezpośrednio do Stwórcy, strasząc karą za grzechy (m.in. za pijaństwo i cudzołóstwo). Szczególny przypadek dotyczy art. 23, który mówi o niewolnictwie seksualnym.

Litewskiego?" w Kultura religijna i społeczna Małopolski od XIII do XVI wieku, red. Wiktor Szymborski, Janusz Kozioł, (Tarnów: Muzeum Okręgowe w Tarnowie, 2011), 13-21.

56 Paweł Makowiec, „Działalność wojskowa hetmana Floriana Zebrzydowskiego”, Materiały do Historii Wojskowości 2 (2004): 11-17; Marek Plewczyński, „Naczelne dowództwo armii koronnej w latach 1501-1572", Studia i Materiały do Historii Wojskowości 34 (1992): 53-55.

57 Szerzej o tej formie samorządu wojskowego: Jerzy Urwanowicz, Wojskowe „sejmiki”. Koła w wojsku Rzeczypospolitej XVI-XVIII wieku (Białystok: Wydawnictwo Uniwersytetu w Białymstoku, 1996).

58 Karol Łopatecki, „Disciplina militaris” w wojskach Rzeczypospolitej do połowy XVII wieku (Białystok: Instytut Badań nad Dziedzictwem Kulturowym Europy, 2012).

59 Łukasz Bieniasz, „Archipelag innowierstwa - wyznaniowe miasta-wyspy i ich patroni w XVI i XVII wieku na pograniczu polsko-brandenbursko-śląskim”, Orbis Linguarum 52 (2019): 43-44; Stanisław Bodniak, „Cikowski Stanisław h. Radwan”, w Polski słownik biograficzny, red. Władysław Konopczyński, t. 4, (Kraków: PAU, 1938): 73-75. 
Aby przeciwdziałać temu zjawisku, zezwolił on na posiadanie w poczcie jedynie dzieci do sześciu lat, „abowiem chcemyli, aby P. Bog znami był a do wszytkiego dopomagał, niechajże wojsko nasze nie pomazane będzie pijaństwy, cudzołostwy i innemi szpetnemi grzechami etc. Ktoby sie bez tych występkow sprośnych obejść nie mogł, tedy od nas niechaj wyjedzie, a tam już niechaj swą wolą czyni a sądu Pańskiego i karania na stronie krom wojska czeka, a niechaj dla jednego, nas i wszytkiego wojska nie karze ${ }^{60}$ ". W zaprezentowanym fragmencie ukazana jest daleko posunięta racjonalizacja postępowania. Jeżeli Bóg karze za grzechy klęską, należy wyeliminować czyny (przestępstwa), które są szczególnie ciężkie. Jeżeli jednak nie da się tego wyrugować, hetman proponuje opuszczenie wojska. Oczywiście jest to konstrukcja retoryczna - dezercja była karana - bardziej chodziło o złamanie solidaryzmu żołnierskiego. Powyższy cytat dobrze oddaje promowaną ideę i oczekiwania wobec zachowania żołnierzy. „Bojaźń boża” nie miała nic wspólnego z determinizmem i bezradnością, tylko z próbą racjonalizmu i aktywizmu ${ }^{61}$.

W efekcie już w latach 60. XVI wieku rozwinęła się teoria samoograniczenia wodza i żołnierzy, która zastąpiła koncepcję niemal nieograniczonej dominacji utylitaryzmu w działaniu.

$\mathrm{Z}$ zestawienia podanego $\mathrm{w}$ tabeli $\mathrm{nr} 1$ jednoznacznie wynika, że „bojaźń Boża” była propagowana przez dowódców niezależnie od ich wyznania: wśród twórców są katolicy, ewangelicy reformowani, bracia polscy, mamy również konwertytę - Augusta II, który jeszcze rok przed wydaniem artykułów wojskowych był luteraninem ${ }^{62}$. Urszula Augustyniak chce widzieć $\mathrm{w}$ działaniach ewangelików reformowanych łącznik pomiędzy nauczaniem Kalwina a kształtowanym się ideałem ${ }^{63}$. Myślę, że warto w przyszłości pochylić się nad tymi zagadnieniami z perspektywy teologicznej. Jest to tym bardziej zasadne, że w przeciwieństwie do norm prawnych, które rzadko i w nieznacznym tylko stopniu się zmieniały, arenga zaczynająca akt normatywny od przypomnienia bojaźni i namacalnej obecności Boga była formułą dynamiczną ${ }^{64}$. Sądzę, że z tych wstępów można wywnioskować - o ile nie cechy charakteru wodza - to przynajmniej pewien teologiczno-filozoficzny światopogląd. Zgromadzone

60 Polskie ustawy..., 126.

61 Augustyniak, W stużbie hetmana, 128-133.

62 Również fragment o „bojaźni Bożej” z artykułów Władysława IV Wazy (1633) jest powtórzeniem protestanckich praw wojskowych ze Szwecji.

63 Augustyniak, W stużbie hetmana, 132.

64 Rzadkie są sytuacje, w których hetmani przepisują arengi od swych poprzedników wyjątkowa sytuacja dotyczy Michała Kazimierza Paca i jego artykułów z 1673 r. 
arengi można pogrupować w dwie kategorie. Pierwsza mieści opisy odnoszące się jedynie do pozytywnych działań Boga, druga te, które ukazują obie możliwości, w zależności od postępowania żołnierzy - zarówno nagrodę, jak i karę za grzechy. Generalizując, chronologicznie wcześniejsze akty normatywne bardziej akcentują sankcje grożące za popełniane przestępstwa; te późniejsze mają bardziej pozytywny charakter.

Oczywiście w narracji związanej z Kościołem rzymskokatolickim pisarze próbowali stworzyć odmienną wizję oceny zachodzących zjawisk. Przykładowo, Bartosz Paprocki zjawisko to opisał w renesansowym traktacie Hetman albo własny konterfekt hetmański, a konkretnie w rozdziale XVI zatytułowanym „O służbie Bożej” ${ }^{65}$. Charakteryzując istotną rolę kapelanów wojskowych, ujawnia swoje poglądy o naturze wojny i sprawczej roli Boga. Według niego, współczesne mu czasy stanowią świadectwo odwracania się Boga od armii polskiej i litewskiej. Przeciwstawiał on złote czasy jedności religijnej w Rzeczypospolitej, które oznaczały się szczytem potęgi militarnej i pomyślności zsyłanej przez Boga. Dwukrotnie odwoływał się przy tym do czasów panowania Władysława Jagiełły i bitwy pod Grunwaldem, gdzie dostrzegał namacalną pomoc Stwórcy. Przywoływał on zasięg terytorialny władztwa Jagiellonów: „między dwoie morza Polska szerokie granice rozciągała”. Oczywiście Paprocki nie dostrzega (lub pomija) czynników niezgadzających się z tą wizją, a zatem milczy o żołnierzach prawosławnych, husytach i muzułmanach walczących w armii Jagiełły i Witolda. Według niego pobożność wprowadzona przy pomocy katolickich kapelanów wojskowych, w połączeniu z jednolitym wyznaniem, gwarantować powinna sukces militarny. Obecna różnorodność religijna była, zdaniem autora, przyczyną kolejnych strat terytorialnych ${ }^{66}$.

Następcy Paprockiego rozwijali te treści, co na poziomie decyzyjnym miało skutkować ograniczeniem obecności kapelanów innych niż katolickiego wyznania ${ }^{67}$. W szczególności należy zaakcentować twórczość jezuitów, a przede wszystkim wybitnego ich przedstawiciela - Piotra Skargi.

65 Bartosz Paprocki, Hetman albo własny konterfekt hetmański, skad sye siła woiennych postepkow każdy nauczyć może (Kraków: Drukarnia Mattheusza Syebeneychera, 1578), E-Ei.

66 Zupełnie odwrotnie argumentował Andrzej Lubieniecki, Poloneutychia, oprac. Alina Linda, Maria Maciejewska, Janusz Tazbir, Zdzisław Zawadzki (Warszawa-Łódź: PWN, 1982), 106-164, który w prześladowaniu innowierców widzi gniew Boży spadający na Rzeczpospolitą.

67 Karol Łopatecki, „Cuius regio eius religio w wojskach Rzeczypospolitej? Kwestia wolności głoszenia wiary wśród żołnierzy w latach dwudziestych XVII wieku”, w: Studia nad Reformacją, red. Elżbieta Bagińska, Piotr Guzowski, Marzena Liedke, (Białystok: Uniwersytet w Białymstoku, 2010), 37-50. 
W wydanych w 1597 roku Kazaniach sejmowych wskazywał, że niekatolicki żołnierz służący w wojskach Rzeczypospolitej, ignorując wzywanie pomocy świętych i Maryi, może doprowadzić do zguby nawet najpotężniejszą armię. Łaska Boga i zesłanie przez Niego zwycięstwa uzależnione są od obecności w obozach wojskowych kapłanów katolickich ${ }^{68}$.

Generalnie jednak „bojaźń Boża” nie miała charakteru wykluczającego, odnosiła się przede wszystkim do faktycznych postaw, a nie deklarowanego wyznania. W sposób niezwykle obrazowy opisali związek przyczynowo-skutkowy pomiędzy pobożnością a efektem działań wojennych Krzysztof Myszkowski (1572) i Krzysztof Radziwiłł Piorun (1601). Z kaźni (kary) rodzi się bojaźń, ta zaś przekłada się na miłość, co następnie wpływa na porządek, a w efekcie na łaskę Bożą, czyli zwycięską wojnę ${ }^{69}$. Powyższe relacje ukazują, że idei bojaźni Bożej nie wolno utożsamiać z zabobonami, magicznym prymitywizmem w ocenie zachodzących zjawisk. Wręcz przeciwnie - założenia opierały się na racjonalnych podstawach. Przywołam jeszcze raz Jana Michała Kampenhausena, który odnotował:

[...] wiem barzo dobrze, iż każde zwycięstwo jest od Boga samego i wszytkie porządki są za nic bez jego pomocy, ale Bóg jest Bogiem porządku i w porządnych wojska i wodzach kocha się, a przynajmniej od siła złego zachowa i choć przegraną karze, to też drugą stronę choćby wygrał, nawiedzy, aby siła straciła i drogo wygranej nabywała, abo nie barzo z niej się ucieszyła $^{70}$.

W innym miejscu autor zwraca uwagę na sposób porządkowania faktów i wyciągania wniosków opartych na doświadczeniu. To zaś dowodziło, że nie mogą mieć zastosowania prawa matematyczne, o czym pisze też Jan Zamoyski w 1589 roku (zob. tabela nr 1, LP. 7) ${ }^{71}$. Większa liczebność, artyleria, zapasy gotówki wcale nie gwarantują zwycięstwa. W rozumieniu współczesnych coś innego, trudnego do uchwycenia, rozstrzygało

68 Piotr Skarga, Kazania sejmowe, wyd. Janusz Tazbir, (Wrocław-Warszawa-Kraków: Zakład Narodowy im. Ossolińskich, 1995), 101-104; Kamila Wincewicz, „Językowy obraz Boga w Kazaniach sejmowych Piotra Skargi”, Linguarum Silva 4 (2015): 85-86. Szerzej o żołnierzu-katoliku w Rzeczypospolitej szlacheckiej: Lenart, Miles pius..., passim.

69 Nieco inaczej ukazali splot powiązań konfederacji z lat 1659-1661. Wszelka pomyślność wynikać ma z błogosławieństwa Bożego, ta zaś wynika z bojaźni Bożej, która opiera się na karaniu, a ono ma swój fundament na wymiarze sprawiedliwości.

70 Biblioteka Kórnicka PAN, rkps 659, k. 132v-133.

71 Podobną argumentację odnajdujemy w artykułach hetmańskich Jana Zamoyskiego z $1589 \mathrm{r}$. 
o rezultacie wojny ${ }^{72}$. Takim czynnikiem miał być Bóg i w taki sposób pobożność została wprzęgnięta w istotę prowadzenia wojny.

Analizując kolejne arengi rozpoczynające artykuły wojskowe, widzimy, że stałym ich czynnikiem był wpływ religijności na dyscyplinę wojskową i morale (co określano wyrażeniem "dobre serce” - zob. regulację Mikołaja Mieleckiego z 1572 r.). Jej znaczący wpływ na podniesienie walorów bojowych w okresie wczesnonowożytnym jest tezą niepodlegającą dyskusji ${ }^{73}$. Wysokie morale i dyscyplina są bardzo często wyróżnikiem zwycięskiej armii, natomiast większość niepowodzeń ma bezpośredni związek z lekceważeniem zasad bezpieczeństwa, porządku czy hierarchii wojskowej. Pobożność rozumiana jako osadzenie działań żołnierzy i oficerów w systemie reguł prawa wojskowego i powtarzalnych czynności, które umacniają religijność wśród żołnierzy, miała swoje przełożenie na skuteczność działań wojennych, przynajmniej do czasów wojen napoleońskich ${ }^{74}$.

W kolejnych dziesięcioleciach wieków XVI i XVII rozwijano ideę bojaźni Bożej, a w konsekwencji otrzymujemy coraz bardziej rozbudowane formuły. W artykułach Stefana Batorego z 1581 roku znajdujemy informację, jak można umacniać tę cechę. Miało być to możliwe poprzez modlitwy i czyste sumienie (czyli niepopełnianie przestępstw), co później było często powielane ${ }^{75}$. Coraz większego znaczenia nabierało wyrugowanie z armii wszelkich przejawów magii, co odnotowano w 1633 roku. Jan Zamoyski jako pierwszy (1593) wprowadził określenie „Bóg wojsk i zastępów”, które następnie zostało spopularyzowane w najważniejszych w okresie nowożytnym artykułach wojskowych aprobowanych na sejmie 1609 roku $^{76}$. Najbardziej rozbudowane i przemyślane formy

72 Biblioteka Kórnicka PAN, rkps 659, k. 10v: „Nie chrześci[j]anin ale gorszy od Poganina, ktoby wątpił, iż zwycięstwo nie jest od Pana Boga i kto jest, ktoby temu chciał przeczyć, kiedy widziemy, iż czasem słabsi i mniejszej liczby ludzie przeciwko olbrzymom i barziej mocniejszym, tak dobrze i czasem jeszcze lepiej stawają i wygrywają, a ci którzy najmocniejszych przezwyciężali od słabszych zwyciężenie bywają".

73 Lenart, Miles pius..., passim. Różnice zdań dotyczą siły oddziaływania i oceny najskuteczniejszych sposobów wykorzystania religii w utylitarnych celach wojskowych. Warto jednak odnotować, że część historiografii w okresie PRL-u ukazywała to zjawisko w ujęciu negatywnym. Zob. Józef Karwin, Edward Pomiarowski, Stanisław Rutkowski, Z dziejów wychowania wojskowego w Polsce od początku państwa polskiego do 1939 roku (Warszawa: Wydawnictwo MON, 1969), 49.

74 Dominującą cechą odpowiedzialną za morale zaczął odgrywać patriotyzm. Alan Forrest, Napoleon's men: the soldiers of the revolution and empire (London: Bloomsbury Academic, 2006).

75 Od 1609 r. był również akcentowany dobry przykład dawany przez dowódców i towarzyszy swoim podwładnym.

76 W 1618 r. skrócono określenie, pisząc o „Panu Zastępów”. 
zastosowano w litewskich artykułach wojskowych Krzysztofa Radziwiłła, Janusza Radziwiłła, Michała Kazimierza Paca oraz Michała Kazimierza Radziwiłła w latach 1633, 1635, 1648, 1673, 1746. W nich najwyraźniej dostrzec można korelację pomiędzy przestępstwami wojskowymi a gniewem Bożym i zsyłaną karą podczas wojen. Związek ten jest również wyraźnie widoczny w przepisach prawnych z lat 1698 i 1749.

Idee, które cytuję w tabeli nr 1, wskazują, że ich żywotność była bardzo duża. Wynikało to, w moim odczuciu, z kilku kwestii - przede wszystkim hetmani wzorowali się na swoich poprzednikach. Gdyby jednak ten element był decydujący, wszystkie arengi miałyby zbliżoną treść. Dlatego chciałbym zaakcentować dwa kolejne elementy. Po pierwsze, zagadnienie bojaźni Bożej stanowiło ważny element wychowania i edukacji szlacheckiej $^{77}$. Znamy nawet przykłady, kiedy hetman swemu synowi narzucał tę koncepcję jako fundament kształcenia i pobożności. Tak uczynił m.in. Krzysztof (II) Radziwiłł wobec swego syna - Janusza ${ }^{78}$. Dodam, że obaj stworzyli rozbudowane, ale znacznie różniące się w treści wstępy do artykułów wojskowych (tablica nr 1, LP. 11-12, 14-16). Trzecim elementem było wychowanie wojskowe, którego istotną składową były cyklicznie czytane artykuły wojskowe, a zawarte w nich idee indywidualnie interpretowane przez żołnierzy na bazie własnych przeżyć i doświadczeń ${ }^{79}$.

Niewątpliwie ten w gruncie rzeczy pragmatyczny osąd rzeczywistości wojennej, w sytuacjach jednostkowych był nieco groteskowy. Humorystycznym, lecz trafnym opisem jest relacja Jana Chryzostoma Paska, który podkreślał, że podczas szturmu nakazał „swoim wołać «Jezus, Maryja!», lubo insi wołali: «Hu, hu, hu!», bom się spodziewał, że mi więcej pomoże Jezus niżeli ten jakiś pan Hu" ${ }^{\text {". }}$. Natomiast Jan Władysław Poczobut Odlanicki znajduje przyczyny swoich niepowodzeń w tym, że „mię snać Pan Bóg skarał właśnie, żem miawszybyć niechybnie nabożny w dzień [Najświętszej Panny Anielskiej] (...) upiłem się z tym kalwinem

77 Przykładowo: Wacław Kunicki, Obraz szlachcica polskiego, (Kraków: Drukarnia Dziedziców Jakuba Siebeneichera, 1615), k. Bv-B3v.

78 Mariola Jarczykowa, „»Obowiązkowe« i »nadobowiązkowe« lektury Janusza II Radziwiłła w czasie jego nauki w liceum słuckim i podczas zagranicznych studiów”, w Młody czytelnik $w$ świecie książki, biblioteki i informacji, red. Krystyna Heska-Kwaśniewicz, Irena Socha, (Katowice: Wydawnictwo Uniwersytetu Śląskiego, 1996), 29.

79 Przykładowo: Jan Ryś, Żołnierska paideia. Wychowanie i szkolenie wojskowe w Polsce XVI-XVII wieku (Kraków: Wydawnictwo Naukowe Akademii Ignatianum w Krakowie, 2019).

80 Jan Chryzostom Pasek, Pamiętniki, oprac. Władysław Czapliński, (Wrocław: Zakład Narodowy im. Ossolińskich, 1979), 31; Iwona Maciejewska, „Bóg zgody, zemsty, sprawiedliwości - o poezji rokoszu Zebrzydowskiego", Napis 12 (2006): 46. 
Wołkiem i jeszcze na pojedynek wychodziłem w te święto" ${ }^{\text {11 }}$ W końcu warto przywołać sytuację z Rokoszu Lubomirskiego. Przedstawiane wówczas sprzeczne racje dworu i hetmana dezorientowały zwykłego żołnierza. Jak wspomina Jan Łoś, wojsko rokoszowe zdało się więc na to, aby Bóg w bitwie „rozsądzić raczył za sprawiedliwą stroną, ponieważ rozum ludzki na allegata tej i owej strony justifikującej się podołać niemógł"

Oczywiście analizowanego oddziaływania wynikającego z bojaźni Bożej nie należy oceniać jako silnego bodźca behawioralnego. Była to idea pomocna, ale nie decydująca w kształtowaniu właściwych postaw i narzuceniu dyscypliny wojskowej. Własne (indywidualne) i wspólnotowe (żołnierskie) dobro było czymś znacznie bardziej namacalnym niż niebezpieczna, ale jedynie potencjalna groźba kary boskiej. Warto podać przykład z okresu całkowitego rozpadu dyscypliny i moralności w czasach dymitriady. Mikołaj Marchocki relacjonował grabież przez żołnierzy skarbca carskiego, w tym szczerozłotego posągu Jezusa. „Naszych chciwość i Panu Jezusowi nie przepuściła, choć były niektórych perswazje, żeby go całkiem do krakowskiego kościoła zamkowego, na wieczną pamiątkę odesłać. Jak się im dostało ze skarbu moskiewskiego, między się, na sztuki porąbawszy podzielili”"83. Jest to dobra puenta ukazująca miejsce bojaźni Bożej w skali realnego oddziaływania. Sam fakt zastanawiania się nad postępowaniem wobec drogocennych rzeźb jest jednak istotny.

Oceniam, że normy prawne znajdujące oparcie w bojaźni Bożej były znacznie skuteczniejszym środkiem perswazji niż inne normy (i sankcje) religijne lub społeczne. Przykładowo: próby dyscyplinowania skonfederowanych żołnierzy groźbą nieudzielenia rozgrzeszenia nie wywołały efektu ${ }^{84}$. Wątpliwy charakter miało również oddziaływanie poprzez

81 Jan Władysław Poczobut Odlanicki, Pamiętnik [1640-1684], oprac. Andrzej Rachuba, (Warszawa: Czytelnik, 1987), 170-171.

82 Jakub Łoś, Pamiętniki Łosia, towarzysza choragwi pancernej, wyd. Żegota Pauli, (Kraków: Nakładem księgarni D.E. Friedleina, 1858), 83.

83 Mikołaj Ścibor Marchocki, „Historia moskiewskiej wojny prawdziwa...”, w Moskwa w rękach Polaków. Pamiętniki dowódców i oficerów garnizonu polskiego w Moskwie w latach 1610-1612, [oprac. Andrzej Nowosad] (Warszawa: Platan, 1995), 85; Urwanowicz, Wojskowe „sejmiki”, 61.

84 O konfederacyi lwowskiej, w roku 1622 uczynionej, nauka, wyd. Kazimierz Józef Turowski (Kraków: Wydawnictwo Biblioteki Polskiej, 1858), 14-20; Jerzy Pietrzak, „Konfederacja lwowska w 1622 roku”, Kwartalnik Historyczny 80/4 (1973): 859. Również w czasie konfederacji 1613-1614 r. duchowieństwo groziło karami kościelnymi. Kazimierz Tyszkowski, „Problemy organizacyjno-wojskowe z czasów wojny moskiewskiej Zygmunta III", Przeglad Historyczno-Wojskowy 2 (1930): 281. 
naukę wygłaszaną przez spowiedników ${ }^{85}$. Znamienna jest również reakcja hetmana wielkiego litewskiego Kazimierza Jana Sapiehy, którego ekskomunikował biskup wileński. Wódz z tej okazji „z dział bić kazał i race puszczać, (...) Żydów po biskupiu ubierano dla pośmiewiska" ${ }^{86}$. Natomiast kara Boża spadająca „tu i teraz” na występnych żołnierzy i całe armie stanowiła silniejszy argument. W sposób niezwykle obrazowy opisał to Szymon Starowolski oceniając naganne czyny skonfederowanych żołnierzy. Ich koniec miał być tragiczny: „wszystkich wybito, wywieszano, wyćwiertowano [...] drugich też choroby sprosne i nagła śmierć pożarła”. Konfederaci ginęli często w sposób nadprzyrodzony: „Nawet sami czarci łby urywali”, Starowolski uwiarygadnia swoje obserwacje zeznaniami naocznych świadków tych wydarzeń: „siła jeszcze takich co ich znali, ba i patrzali na ich śmierć nieszczęśliwą". Wytłumaczeniem owego fenomenu jest wola Boża, która: „onych szarpańców karze, i karać będzie wiecznie, i ojczyznę wszystkę plagami rozmaitemi nawiedza" ${ }^{\prime 7}$. Taka narracja miała szansę szerokiego oddziaływania wśród żołnierzy, być może po wynagrodzeniu materialnym najważniejszą w okresie staropolskim. Podkreślić należy, że miała ona realny wpływ na wychowanie wojskowe.

Podsumowując, za twórców wpojenia w środowisku żołnierskim idei bojaźni Bożej uważam: Floriana Zebrzydowskiego (katolik), Jana Chodkiewicza (ewangelik reformowany) i Stanisława Cikowskiego (arianin). Była to więc zróżnicowana grupa dowódców - Polaków i Litwinów walczących w latach 60 . XVI stulecia w Inflantach. Spory doktrynalne i teologiczne odgrywały drugorzędną rolę, kluczowe było sprawne zarządzanie armią oraz wpojenie żołnierzom zasad postępowania, które realnie zwiększałyby poziom morale i dyscypliny. Do twórców najbardziej rozbudowanych koncepcji zaliczyłbym katolików: Jana Zamoyskiego i Michała Kazimierza Radziwiłła oraz ewangelików reformowanych:

85 Wacław Potocki, „Spowiedź żołnierska”, w idem, Dzieła, t. 2: Ogród nie plewiony $i$ inne utwory $z$ lat 1677-1695, oprac. Leszek Kukulski, (Warszawa: Państwowy Instytut Wydawniczy, 1980), 71; Srogosz, Życie codzienne 171. Starano się przy tym, aby każdy z żołnierzy przynajmniej raz do roku przystępował do spowiedzi, co egzekwowano nawet przy pomocy karteczek, na których kapelan potwierdzał obecność żołnierza. Samuel Brodowski, Corpus Juris Militaris Polonicum (Elbląg: Samuel Gottlieb Preuss, (Wdowa), 1753), 6 i 14.

86 Kazimierz Sarnecki, Pamiętniki z czasów Jana Sobieskiego. Diariusz i relacje z lat 16911696, wyd. Janusz Woliński, (Wrocław: Zakład Narodowy im. Ossolińskich, 1958), 121; por. Andrzej Rachuba, „Litwa wobec projektu zwołania sejmu konnego w 1695 r. i walki Sapiehów z biskupem Brzostowskim", Zapiski Historyczne 51/1 (1986): 63-82.

87 Szymon Starowolski, Reformacja obyczajów polskich, wyd. Kazimierz Józef Turowski (Kraków: Wydawnictwo Biblioteki Polskiej, 1859), 111-112. 
Krzysztofa Radziwiłła Pioruna i Krzysztofa (II) Radziwiłła. Analizowana idea istniała przez dwa stulecia, aż do okresu oświecenia, w czasach Stanisława Augusta Poniatowskiego nie jest ona już widoczna. W ujęciu historyczno-prawnym podkreślić należy próbę nadania przestępstwom wojskowym podwójnych sankcji. Z jednej strony, żołnierz popełniający zbrodnię lub występek mógł być skazany przez sąd, z drugiej - grzesznik podpadał pod karę Bożą, która mogła być wyegzekwowana w nieodległym czasie ${ }^{88}$. Innowacyjnym rozwiązaniem była próba złamania solidaryzmu żołnierskiego poprzez groźbę, że liczne nieukarane przestępstwa wywołają gniew Boży, który dotknie całą armię. Na koniec wypada podkreślić, że oczywiście głównym motywem postępowania żołnierzy najemnych i zaciężnych była oczywiście gratyfikacja finansowa (lub jej brak), jednakże niewątpliwie tuż za nią znajdowała się obawa kary doczesnej egzekwowanej czy to przez sądy, czy też - jak wierzono - przez Boga.

\section{Bibliografia}

\section{Archiwalia}

Archiwum Główne Akt Dawnych, Archiwum Radziwiłłów VII, sygn. 5.

Biblioteka Kórnicka PAN, rkps 659.

Biblioteka Książąt Czartoryskich, rkps 1621, 1661, 2446, 2717.

Biblioteka Ossolińskich, Biblioteka im. Gwalberta Pawlikowskiego, rkps 12.

Российская национальная библиотека, Санкт-Петербург, Отдел рукописей, Автографи Дубравскаго (f. 971), 321/1, nr 1, 141.

Российская национальная библиотека, Санкт-Петербург, Отдел рукописей, Автографи Дубравскаго (f. 971), 321/2, nr 42, 197, 243, 283.

Санкт-Петербургский институт истории РАН, Западноевропейска секциа, kolekcja 32, karton 660, nr 2.

\section{Źródła drukowane}

Artykuly woyskowe $=$ Kriegs-Artikel (Warszawa: 1775).

Artykvły woienne powaga Rzeczy Pospolitej krolow polskich y Hetmanów W.X. Litt. rożnymi czasy ustanowione. Teraz zaś z rozkazu Iaśnie Oświeconego Xiążęcia

88 Psychologicznie każde najbardziej nawet przypadkowe wydarzenie, które pasowało do opisu świata, było przez otoczenie przyjmowane jako dowód na prawdziwość twierdzenia, czego przykładami są relacje J.Ch. Paska czy J.W. Poczobuta Odlanickiego. Można to porównać do prognostycznej roli snów, przeczucia, którym ludzkość od zawsze nadawała znaczenie. Por. Emilia Zimnica-Kuzioła, „Główne stanowiska w psychologii religii - wprowadzenie”, Kultura i Wartości 1 (2012): 57-71. 
Iegomości Michała V Kazimierza Radziwiłła (...) przedrukowane (Nieśwież: Nieśwież: Drukarnia Xiążęca Radziwiłłów in Collegio Societatis, 1754).

Brodowski Samuel, Corpus Juris Militaris Polonicum (Elbląg: Samuel Gottlieb Preuss, (Wdowa), 1753).

Kakowski Aleksander, Z niewoli do niepodległości. Pamiętniki (Kraków: Wydawnictwo Platan, 2000).

Kunicki Wacław, Obraz szlachcica polskiego (Kraków: Drukarnia Dziedziców Jakuba Siebeneichera, 1615).

Lubieniecki Andrzej, Poloneutychia, oprac. Alina Linda, Maria Maciejewska, Janusz Tazbir, Zdzisław Zawadzki (Warszawa-Łódź: PWN, 1982).

Łoś Jakub, Pamiętniki Łosia, towarzysza choragwi pancernej, wyd. Żegota Pauli (Kraków: Nakładem księgarni D.E. Friedleina, 1858).

Marchocki Mikołaj Ścibor, „Historia moskiewskiej wojny prawdziwa...”, w: Moskwa w rękach Polaków. Pamiętniki dowódców i oficerów garnizonu polskiego w Moskwie w latach 1610-1612, wyd. Andrzej Nowosad (Warszawa: Wydawnictwo Platan, 1995).

Medeksza Stefan Franciszek, Księga pamiętnicza, wyd. Władysław Seredyński (Kraków: Akademia Umiejętności, 1875).

O konfederacyi lwowskiej, w roku 1622 uczynionej, nauka, wyd. Kazimierz Józef Turowski (Kraków: Wydawnictwo Biblioteki Polskiej, 1858).

Paprocki Bartosz, Hetman albo własny konterfekt hetmański, skąd sye siła woiennych postepkow każdy nauczyć może, (Kraków: Drukarnia Mattheusza Syebeneychera, 1578).

Pasek Jan Chryzostom, Pamiętniki, oprac. Władysław Czapliński, (Wrocław: Zakład Narodowy im. Ossolińskich, 1979).

Poczobut Odlanicki Jan Władysław, Pamiętnik [1640-1684], oprac. Andrzej Rachuba, (Warszawa: Czytelnik, 1987).

Polskie ustawy i artykuły wojskowe od XV do XVIII wieku, wyd. Stanisław Kutrzeba (Kraków: Polska Akademia Umiejętności, 1937).

Potocki Wacław, Dzieła, t. 2: Ogród nie plewiony i inne utwory z lat 1677-1695, oprac. Leszek Kukulski, (Warszawa: Państwowy Instytut Wydawniczy, 1980). Sarnecki Kazimierz, Pamiętniki z czasów Jana Sobieskiego. Diariusz i relacje z lat 1691-1696, wyd. Janusz Woliński, (Wrocław: Zakład Narodowy im. Ossolińskich, 1958).

Sarnicki Stanisław, Księgi hetmańskie, oprac. Marek Ferenc, (Kraków: Historia Iagiellonica, 2015).

Schneeberger Anton, De Bona Militum Valetudine Conservanda Liber, oprac. R.A. Sucharski, T.M. Nowak, (Warszawa: DiG, 2008).

Siedlecki Adam Grzymała, Cud Wisły. Wspomnienia korespondenta wojennego (Warszawa: Wiedza Powszechna, 1921).

Starowolski Szymon, Reformacja obyczajów polskich, wyd. Kazimierz Józef Turowski, (Kraków: Wydawnictwo Biblioteki Polskiej, 1859).

Schwedisches Kriegs-Recht oder Articuls-Brieff desz ... Herrns Gustaff Adolffs ... (Heylbrunn: b.d., 1632). 
Tarnowski Jan, Consilium Rationis Bellicae, oprac. Tadeusz Marian Nowak, wstęp Janusz Sikorski, (Warszawa: MON, 1987).

Volumina Legum, t. 2, (Petersburg: Józefat Ohryzko, 1859).

\section{Książki i monografie}

Augustyniak Urszula, W stużbie hetmana i Rzeczypospolitej. Klientela wojskowa Krzysztofa Radziwiłła (1585-1640) (Warszawa: Semper, 2004).

Bodniak Stanisław, „Cikowski Stanisław h. Radwan”, w Polski słownik biograficzny, red. Władysław Konopczyński, t. 4, (Kraków: 1938): 73-75.

Borzęcki Jerzy, Pokój ryski w 1921 roku i kształtowanie się międzywojennej Europy Wschodniej (Warszawa: Polski Instytut Spraw Międzynarodowych, 2012).

Cisek Janusz, Paduszek Konrad, Rawski Tadeusz, Wojna polsko-sowiecka 19191921 (Warszawa: Wojskowe Centrum Edukacji Obywatelskiej, 2010).

Davies Norman, Biały orzeł, czerwona gwiazda. Wojna polsko-bolszewicka 19191920, tłum. A. Pawelec, (Kraków: Wydawnictwo Znak, 1997).

Dworzaczek Włodzimierz, Hetman Jan Tarnowski. Z dziejów możnowładztwa małopolskiego (Warszawa: Pax, 1985).

Forrest Alan, Napoleon's men: the soldiers of the revolution and empire (London: Bloomsbury Academic, 2006).

Giejło Jacek, Bohater spod Ossowa: Ignacy Jan Skorupka: 1893-1920 (Warszawa: S.I. „Warta” Gorzów Wielkopolski, 2010).

Hołda Renata, „Wojna 1920 roku we współczesnym dyskursie pamięci”, w Ciekawość świata, ludzi, kultury... Księga jubileuszowa ofiarowana Profesorowi Ryszardowi Kantorowi z okazji czterdziestolecia pracy naukowej, red. Renata Hołda, Tadeusz Paleczny, (Kraków: Księgarnia Akademicka, 2012), 247-261.

Instrukcja wydawnicza dla źródeł historycznych od XVI w. do poł. XIX w., red. Kazimierz Lepszy, (Wrocław: Zakład im. Ossolińskich, 1953).

Jarczykowa Mariola, „»Obowiązkowe« i »nadobowiązkowe« lektury Janusza II Radziwiłła w czasie jego nauki w liceum słuckim i podczas zagranicznych studiów”, w Młody czytelnik w świecie książki, biblioteki i informacji, red. Krystyna Heska-Kwaśniewicz, Irena Socha, (Katowice: Wydawnictwo Uniwersytetu Śląskiego, 1996), 22-33.

Karwin Józef, Pomiarowski Edward, Rutkowski Stanisław, Z dziejów wychowania wojskowego w Polsce od początku państwa polskiego do 1939 roku (Warszawa: Wydawnictwo MON, 1969).

Kotecki Radosław, „Ordynariusz płocki Szymon w Gallowej narracji o bitwie Mazowszan z Pomorzanami (Gall II, 49)”, w Ecclesia et bellum. Kościół wobec wojny i zaangażowania militarnego duchowieństwa $w$ wiekach średnich, red. Radosław Kotecki, Jacek Maciejewski, (Bydgoszcz: Wydawnictwo Uniwersytetu Kazimierza Wielkiego, 2016), 142-167.

Кром Михаил Маркович, Стародубская война 1534-1537. Из истории русско-литовских отношений (Москва: Рубежи XXI, 2008).

Kukiel Marian, Bitwa Warszawska, wyd. Krzysztof Filipow, Zbigniew Wawer (Warszawa: Polski Instytut Wydawniczy 2005). 
Lenart Mirosław, Miles pius et iustus: żołnierz chrześcijański katolickiej wiary w kulturze i piśmiennictwie dawnej Rzeczypospolitej (XVI-XVIII w.) (Warszawa: Instytut Badań Literackich PAN, 2009).

Łopatecki Karol, „Cuius regio eius religio w wojskach Rzeczypospolitej? Kwestia wolności głoszenia wiary wśród żołnierzy w latach dwudziestych XVII wieku”, w: Studia nad Reformacja, red. Elżbieta Bagińska, Piotr Guzowski, Marzena Liedke, (Białystok: Uniwersytet w Białymstoku, 2010), 37-50.

Łopatecki Karol, „Czy Jan Tarnowski jest twórcą prawa wojskowego na terenie Korony i Wielkiego Księstwa Litewskiego?", w Kultura religijna i społeczna Małopolski od XIII do XVI wieku, red. Wiktor Szymborski, Janusz Kozioł, (Tarnów: Muzeum Okręgowe w Tarnowie, 2011), 13-21.

Łopatecki Karol, „Koncepcja Boga - Pana Historii wśród żołnierzy Rzeczypospolitej na przełomie XVI i XVII wieku", w Religia wobec historii, historia wobec religii, red. Elżbieta Przybył, (Kraków: Wydawnictwo WAM, 2006), 360-370.

Łopatecki Karol, „Disciplina militaris” w wojskach Rzeczypospolitej do połowy XVII wieku (Białystok: Instytut Badań nad Dziedzictwem Kulturowym Europy, 2012).

Muchliński Antoni, Źródłosłownik wyrazów które przeszły, wprost czy pośrednio, do naszéj mowy z języków wschodnich, tudzież mających zobopólna analogje co do brzmienia lub znaczenia (Petersburg: Cesarska Akademia Nauk, 1858).

Nestorow Rafał, „Jan Kampenhausen. Inżynier na usługach hetmana Adama Mikołaja Sieniawskiego", w Fides Ars Scientia. Studia dedykowane pamięci Księdza Kanonika Augustyna Mednisa, red. Andrzej Betlej, Józef Skrabski, (Tarnów: Muzeum Okręgowe w Tarnowie, 2008), 315-326.

Nowak Andrzej, Ojczyzna Ocalona. Wojna sowiecko-polska 1919-1920 (Kraków: Biały Kruk, 2012).

Organiściak Wojciech, Kodeksy wojskowe w Polsce roku 1775 (Katowice: Wydawnictwo Uniwersytetu Śląskiego, 2001).

Ronikier Jerzy, Hetman Adam Sieniawski i jego regimentarze. Studium z historii mentalności szlachty polskiej 1706-1725 (Kraków: Universitas, 1992).

Ryś Jan, Żołnierska paideia. Wychowanie i szkolenie wojskowe w Polsce XVI-XVII wieku (Kraków: Wydawnictwo Naukowe Akademii Ignatianum w Krakowie, 2019).

Rytter Grażyna, Wschodniosłowiańskie zapożyczenia leksykalne w polszczyźnie XVII wieku (Łódź: Wydawnictwo Uniwersytetu Łódzkiego, 1992).

Sikorski Andrzej, Spolonizowane rodziny inflanckie. I. Kampenhausenowie, http:// www.bkpan.poznan.pl/ biblioteka/JW70/kampen.htm (dostęp: 12. 07. 2021).

Skarga Piotr, Kazania sejmowe, wyd. Janusz Tazbir, (Wrocław-Warszawa-Kraków: Zakład Narodowy im. Ossolińskich, 1995).

Srogosz Tadeusz, Życie codzienne żotnierzy armii koronnej i litewskiej w XVII wieku (Oświęcim: 2018).

Urwanowicz Jerzy, Wojskowe „sejmiki”. Koła w wojsku Rzeczypospolitej XVIXVIII wieku, Białystok: Wydawnictwo Uniwersytetu w Białymstoku, 1996. 
Wysocki Wiesław Jan, „Kościół polski wobec najazdu bolszewickiego w 1920 roku”, w W nieustającej trosce o polską diasporę. Tom studiów historycznych i politologicznych dedykowany Księdzu Arcybiskupowi Szczepanowi Wesołe$m u$, red. Roman Nir, Marek Szczerbiński, Krzysztof Wasilewski, (Gorzów Wielkopolski: Stowarzyszenie Naukowe „Polska w Świecie”, 2012), 81-96.

Wyszczelski Lech, Bitwa na przedpolach Warszawy (Warszawa: Wydawnictwo Bellona, 2008).

Wyszczelski Lech, Warszawa 1920 (Warszawa: Wydawnictwo Bellona, 2005).

\section{Czasopisma}

Bańdo Adam, „Bitwa Warszawska 1920 r. w serwisie informacyjnym „Ilustrowanego Kuriera Codziennego" (w setną rocznicę "Cudu nad Wisłą ")”, Rocznik Historii Prasy Polskiej 23/2 (2020): 155-168.

Bauer Marcin, „Religijny wymiar scen batalistycznych w pamiętnikach Samuela i Bogusława Kazimierza Maskiewiczów", Senoji Lietuvos literatūra 32 (2011): 103-114.

Bieniasz Łukasz, „Archipelag innowierstwa - wyznaniowe miasta-wyspy i ich patroni w XVI i XVII wieku na pograniczu polsko-brandenbursko-śląskim”, Orbis Linguarum 52 (2019): 37-57.

Dziadosz Dariusz, „Boża i ludzka wierność. Teologiczny obraz zdobycia Kanaanu”, Verbum Vitae 11 (2007): 43-66.

Dziadosz Dariusz Antoni, „Ideowy i teologiczny podtekst misji »wodza zastępów JHWH« w Joz 5, 13-15”, Biblica et Patristica Thoruniensia 13/1 (2020): 25-58.

Jasinski Mirosław, „Motyw zwycięskiej modlitwy w narracji JOZ 10,1-27”, Verbum Vitae 22 (2012): 15-46.

Jędraszewski Marek, „Opatrzność Boża w świetle filozofii”, Studia Theologica Varsaviensia 48/2 (2010): 63-91.

Krasowski Andrzej, „Jozue - pomocnik Mojżesza i posłuszny wojownik Pana”, Itinera Spiritualia 8 (2015): 187-197.

Krokosz Paweł, „Aspekt religijny w strukturach rosyjskich sił zbrojnych za panowania Piotra I”, Украӥна в Центрально-Східній Європі 15 (2015): 210-236.

Kuran Michał, „Struktura i problematyka kazań tryumfalnych Piotra Skargi wygłaszanych z okazji zwycięstw wojennych", Acta Universitatis Lodziensis. Folia Litteraria Polonica 21/3 (2013): 209-224.

Łopatecki Karol, „Religijność żołnierzy w świetle artykułów wojskowych - założenia metodologiczne”, Orientalia Christiana Cracoviensia 6 (2014): 81-93.

Maciejewski Jacek, „Biskup krakowski Pełka a bitwa nad Mozgawą w 1195 roku", Kwartalnik Historyczny 124/3 (2017): 411-438.

Makowiec Paweł, „Działalność wojskowa hetmana Floriana Zebrzydowskiego”, Materiały do Historii Wojskowości 2 (2004): 11-17.

Milewski Dariusz, „Koronacja Augusta II Mocnego na króla Polski”, Saeculum Christianum 10 (2003): 81-99. 
Morka Mieczysław, „Tematyka batalistyczna w sztuce dworu Jana III”, Biuletyn Historii Sztuki 53/1-2 (1991): 3-26.

Nawracała Tomasz, „»Bojaźń Pańska jest źródłem życia« (Prz 14, 27a). Rozwój pojęcia bojaźni Bożej w historii Kościoła”, Ethos. Kwartalnik Instytutu Jana Pawła II KUL 27/4 (2014): 21-41.

Nowakowski Paweł, „Kilka uwag o problemie dyscypliny w ruchu husyckim”, Episteme 16 (2012): 41-58.

Pawłowski Rafał, „Jan Sobieski jako czytelnik Biblii w świetle Listów do Marysieńki", Tematy i Konteksty 6 (2016): 155-162.

Pietrzak Jerzy, „Konfederacja lwowska w 1622 roku”, Kwartalnik Historyczny 80/4 (1973): 845-871.

Plewczyński Marek, „Naczelne dowództwo armii koronnej w latach 1501-1572”, Studia i Materiały do Historii Wojskowości 34 (1992): 35-66.

Pokora Jakub, „»Fortunae filius«: późnobarokowy portret Michała Hieronima Radziwiłła w Nieborowie”, Saeculum Christianum 10/2 (2003): 23-35.

Rachuba Andrzej, „Litwa wobec projektu zwołania sejmu konnego w 1695 r. i walki Sapiehów z biskupem Brzostowskim”, Zapiski Historyczne 51/1 (1986): 63-82.

Rożek Michał, „Perigrinatio Religiosa”, Folia Historica Cracoviensia 4-5 (19971998): 215-227.

Siemieniec Tomasz, „Bóg jako Pan historii świata i ludzi w świetle Apokalipsy Janowej”, Studia Koszalińsko-Kołobrzeskie 19 (2012): 129-155.

Tyszkowski Kazimierz, „Problemy organizacyjno-wojskowe z czasów wojny moskiewskiej Zygmunta III", Przegląd Historyczno-Wojskowy 2 (1930): 279-293.

Wincewicz Kamila, „Językowy obraz Boga w Kazaniach sejmowych Piotra Skargi", Linguarum Silva 4 (2015): 77-91.

Władyka Wiesław, „»Z fachu profesor...«(Stanisław Stroiński)”, Kwartalnik Historii Prasy Polskiej 31/3-4 (1992): 157-158.

Wojnowski Michał, „Religia a wojskowość bizantyńska w świetle traktatów wojskowych IX-XI wieku”, Przegląd Historyczny 100/2 (2009): 189-205.

Zimnica-Kuzioła Emilia, „Główne stanowiska w psychologii religii - wprowadzenie", Kultura i Wartości 1 (2012): 57-71. 